\title{
Three nineteenth-century Southern African San myths: a study in meaning
}

\author{
J. David Lewis-Williams
}

[T] he words ... are often extremely elliptical and could be very puzzling for some one unfamiliar with Zhũ|twãsi language and culture. (Biesele 1975: 176)

Folklore researchers inevitably engage with theories of myth that have been advanced over the decades, indeed centuries. All of them - to varying degrees leave me uneasy. By and large, they attempt to reconcile and formalize what for 'modern Westerners' are disparate, often contradictory, narratives by placing them in an etic typological framework and by invoking social and psychological factors that may or may not be universal. My reservations derive largely from my work on the extensive manuscript collection of |Xam San (Bushman) verbatim phonetic texts that Wilhelm Bleek (1827-75) and his co-worker Lucy Lloyd (1834-1914) compiled in the 1870s (Spohr 1962; Lewis-Williams 1981; 2000; Deacon and Dowson 1996; Hollmann 2004; Bank 2006; Skotnes 2007; Hewitt 2008; Wessels 2010; McGranaghan 2012; Deacon and Skotnes 2014; Weintroub 2015). Some as convicts, others willingly, the informants travelled from the violent, disintegrating social circumstances of the expanding Cape Colony to the Bleek family's Cape Town residence (Penn 2005; Adhikari 2010). Their |Xam language is no longer spoken.

Today, the Bleek and Lloyd Archive is an integral part of the temporal and geographic mosaic of San ethnographies with all their differences and, importantly, empirically established parallels in specific areas of belief and ritual (Figure 1; Schapera 1930; Lewis-Williams 1981; 2015a; 2015b; Lewis-Williams and Biesele 1978; Barnard 1992; 2007; Biesele 1993; Guenther 1996; Mitchell 2002: 222-6). The mosaic also includes Joseph Orpen's nineteenth-century Maloti record (Orpen 1874; Lewis-Williams 1980; 2003; 2015a; Mitchell and Challis 2008; McGranaghan et al. 2013) and much material collected from twentieth-century linguistic groups living in the Kalahari desert, such as the Ju|'hoansi (!Kung), G|wi, !Xóõ and Naron (see, for example, Bleek 1928; Marshall 1976; 1999; Lee 1979; Silberbauer 1981; Wilmsen 1989; Biesele 1993; Valiente-Noailles 1993; Guenther 1999).

Researchers acknowledge an overlap between forager San beliefs as recorded in this literature and pastoralist Khoekhoe beliefs. Megan Biesele (1993: 34) finds that 'it is very hard to tell the difference between a Bushman story and a Khoikhoi story', but nevertheless allows that 'there are a few interesting

\footnotetext{
J. David Lewis-Williams is Professor Emeritus at the University of the Witwatersrand. His books include The Mind in the Cave: consciousness and the origins of art (2002), Inside the Neolithic Mind: consciousness, cosmos and the realm of the gods (2005, with D. G. Pearce) and Myth and Meaning: San-Bushman folklore in global context (2015). Email: davidlewiswilliams60@gmail. com / david@rockart.wits.ac.za
}

(C) International African Institute 2018 


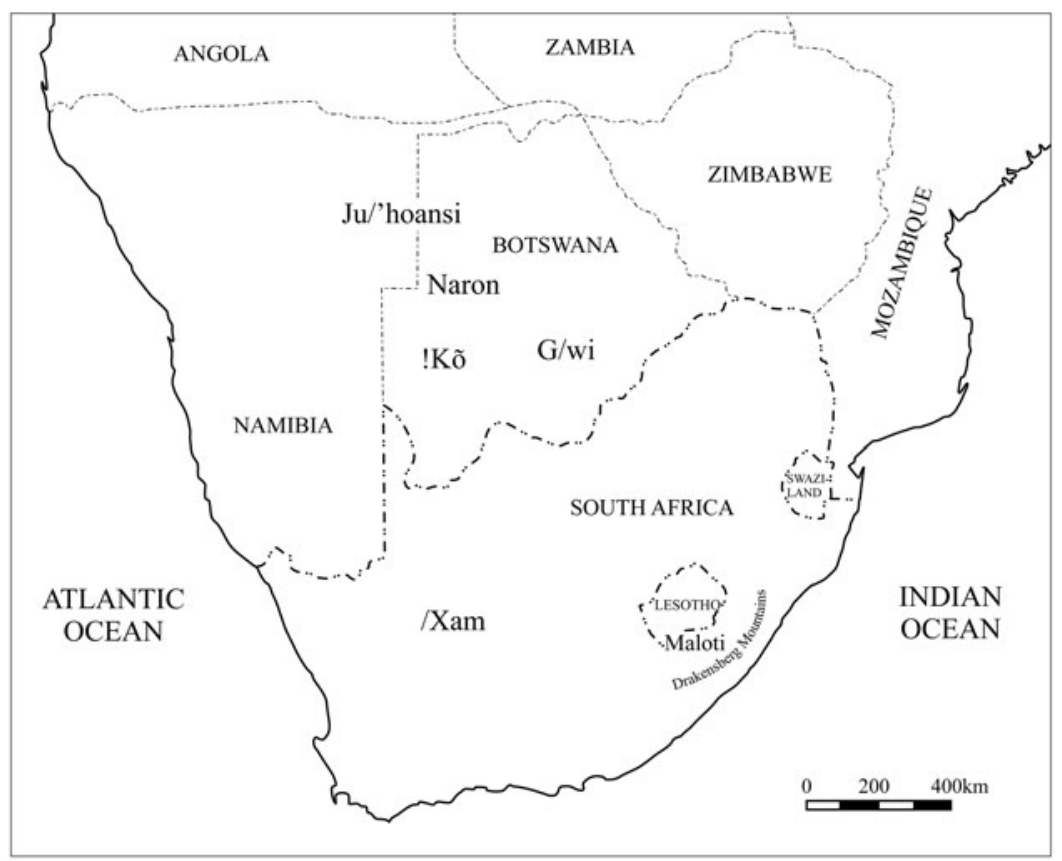

FIGURE 1 Map showing the locations of Southern African San groups.

dissimilarities'. She examines some of these parallels and differences and notes that the folklore of the present-day descendants of the Cape Khoekhoe have been so influenced by European tales that some researchers have catalogued them among Afrikaans tale types (Schmidt 1970: 48). Alan Barnard (1992: 251) similarly concludes that there are 'underlying concepts which cross-cut the ethnic boundaries' (cf. Guenther 1999: 128; Lewis-Williams 2016).

I focus here on the San rather than exploring these cross-cutting concepts. Myths exist in culture-specific performances, not merely in the repeated narrative structures that some folklorists have identified cross-culturally. Some of these structures may well crop up in other Khoisan ethnographies or even worldwide (such as Cinderella-type myths), but exactly what a narrative structure may mean in a specific social context is a more focused matter. It is thus most fruitful to identify and elucidate culture-specific elements in specific performances. Adopting such an approach allows me to elucidate how each San narrative adds something to the depth of our knowledge and settles us further into the complex San milieu. The numerous variants that we have of |Xam narratives may seem kaleidoscopic and unstable (Guenther 1989; 1999; Hewitt 2008; Biesele 1993; Lewis-Williams 1996; 2002; 2015a; Wessels 2010; McGranaghan 2012), but each tale deserves attention because each one, like those I discuss here, reveals new connections within the web of San belief.

Like so much folklore worldwide, these |Xam tales may, at first glance, seem to do no more than reflect the naïve outlook of a 'simple' people who told entertaining stories about the animals around them. Dorothea Bleek, who published parts 
of the collection compiled by her father and Lloyd, seems to take this 'simple' view in the anthology that she titled The Mantis and His Friends. She concluded her introduction by stating that San people remained all their lives 'a child' and were 'above all things fond of hearing and telling stories' (Bleek 1924: unnumbered page).

Enjoying stories is, of course, quite different from understanding their significances. If we set the tales in the web of meanings and beliefs that the |Xam constructed and adapted over the centuries, we begin to discern more than an unaided Western eye is able to see. For one thing, we find that Dorothea Bleek's word 'friends' is a fanciful and infantilizing collective for a complex and fractious group of mythical characters who interact often violently and inconsistently.

In this article, I do not critique other approaches. Instead, by selecting three narratives, I adopt an approach that I feel is less in conflict with the San world that, for me, seeps through the thousands of pages of nineteenth-century phonetic |Xam texts and the more recent San ethnographies (Lewis-Williams 1980; 1981; 1996; 1997; 2000; 2015a; 2016). Other |Xam narratives embody other themes. San mythology is not monolithic: we should therefore be specific rather than synoptic.

\section{A way into San myth}

One way of dealing with San tales is to begin by cataloguing them according to supposed narrative types, the method adopted by Wilhelm Bleek $(1873 ; 1875)$ and Lloyd (1889). More recently, Sigrid Schmidt (1989; 2013) followed a classificatory approach in her valuable catalogues of Khoisan tales. Generally, the approach seems useful because it identifies narrative units that can be recognized even in translation.

I do not argue that units that recur in a number of San tales are unimportant: some are repeated in bewildering guises. The point is that the indigenous significance of recurring events is incomprehensible outside the all-embracing milieu of San thought and social relations. We should not take English recensions at face value. Rather, we need to recognize the narrative surface of a tale and then go beneath it to seek culturally specific meanings.

I therefore consider a number of items that I formerly called 'building-blocks' (Lewis-Williams 1996; 2010; 2013a) but now term 'nuggets' (Lewis-Williams 2015a; 2016). These are single words denoting, for example, animals with wide significances, items of material culture that have rich associations, parts of the natural environment with cryptic connotations, travel by flying and moving underground, and even apparently trivial actions that, for the |Xam, triggered wide-ranging associations. They may also be idiomatic turns of phrase that are opaque to outsiders and make no sense in translation. Though diverse, and therefore hard to define and recognize, nuggets are important because they invoke reticulations of fundamental beliefs and associations that may not be explicit in a text. But, as a narrative proceeds, they add up to an all-embracing cognitive and affective context. They provide a counterpoint to the plot of a tale, enriching its harmonies and resonances. The manifest meaning, or 'lesson', of a narrative (if we assume one can be discerned) should be seen within this, for Westerners, elusive and richly allusive context. Overall, San tales are 'only indirectly didactic' (Biesele 1993: 33). 
Nuggets are thus part of the 'taken-for-granted' aspects of myth. Indigenous narrators often ignore the most important contexts of a tale as being so obvious that they cannot imagine that their auditors do not think in terms of them. They themselves seldom, if ever, articulate them. In ancient Greece, for instance, writers and speakers rarely retold myths in detail. They more commonly merely referred to an incident, character or material object in a myth on the assumption that their readers or hearers would know the full narrative and the implied connotations (Kirk 1974). Although I do not attempt to define the word here, I think this is one of the principal distinguishing features of myths.

Similarly, in traditional circumstances most San hearers were already familiar with the tales. They would mentally fill in 'missing' episodes or details as the narrator progressed. It was therefore not necessary for narrators to spell out every incident in the tales. It was not even necessary that a tale be told through to its end: everyone knew how it ended (Barnard 2013: 65). The taken-for-granted factor was high.

Although she does not use the word, Biesele, who is fluent in the Jul'hoan language, realizes the importance of nuggets. The phrase that I have italicized in the following quotation is central to the approach that I advocate: 'Picking out comparable "elements", however defined, becomes a challenging detective game involving much social knowledge and a wide grasp of the themes and plots in the body of narratives. Often a concrete detail, merely mentioned in passing, is enough to give a social clue with enormous ramifications' (Biesele 1996: 145).

Biesele is not alone in holding this view. Approvingly, Clifford Geertz (1988: 43) quotes Claude Lévi-Strauss:

Exploration is not so much a matter of covering ground as of digging beneath the surface: chance fragments of landscape, momentary snatches of life, reflections caught on the wing - such are the things that alone make it possible for us to understand and interpret horizons which would otherwise have nothing to offer us. (Lévi-Strauss 1961: 50)

Biesele emphasizes the 'extremely elliptical and ... very puzzling' nature of many Ju|'hoan idiomatic phrases (Biesele 1975: 176). Likewise, Nicholas England (1968: 343-4), who studied Ju|'hoan music and song, wrote of "catch words", crammed full of meanings and surrounded by an extensive halo of implicit meanings'. Sometimes such words are omitted from the précis with which many writers work when they deal with myths worldwide, and indeed with tendentious summaries of San tales. Yet, severally and in combination, they underpin and make indigenous sense, rather than some universal sense, of San mythical narratives. This approach contrasts strongly with claims that understanding |Xam texts 'does not require extensive anthropological expertise' (Solomon 2009: 33).

When we explore the nuggets preserved in the Bleek and Lloyd notebooks, we must remember that the recording context was very different from traditional San contexts in which the tales would have been enlarged and dramatized to suit immediate social circumstances. Accordingly, parts of the tales may have been retold in a single performance and thus emphasized. There would also have been gestural embellishments, enactments and songs with their "“catch words", crammed full of meanings'. Another caveat is that, if the Kalahari San are anything to go by, the IXam informants seem to have bowdlerized their narrations to conform to Victorian norms. Finally, the recording of some tales extended over a number 
of days, during which narrators had to pause repeatedly while Bleek or Lloyd wrote down their words. Despite their verbatim transcription, we are, for the most part, dealing with pared-down narratives.

With these provisos in mind, I turn to three tales concerning the abduction of a girl or young woman. In the sequence in which I present them there is a progression from what may possibly be taken to be essentially an everyday event enacted by animal characters to a tale that is clearly set in a mythical realm. There is also a progression from tales in which animals are the protagonists to one in which animals are not mentioned. The Mantis, the |Xam trickster-deity, does not feature in any of the tales (cf. Lewis-Williams 2015a), although the sorts of actions he performs do. The nuggets in each tale point to a level on which it operates that is, as it were, below the narrative surface - a subplot. Two worlds may be discerned: the material world in which real people may be abducted and a realm of supernatural conflict between members of a special category of people, living or dead.

\section{She who was a hurru twiten}

On 9, 10 (two sessions) and 11 March 1875, Diä!kwain, a |Xam informant, told Lloyd the first tale I have selected (Figure 2). He said that he had heard it from his paternal grandmother, Ttwobboken-!kauken. After a four-month (1873-74) stay with the Bleek family he went back to his home but later returned to Cape Town with his sister and brother-in-law for a period of nearly two years (187476). Janette Deacon (1996: 32-5; see also 1986; 1988) convincingly argues that 'he had probably undergone some training as a shaman' who specialized in rainmaking. 'Shaman' is used here and elsewhere in the present article in place of Bleek and Lloyd's 'sorcerer' without implying identity with classic central Asian shamanism (Lewis-Williams 1992; 2012; see also Guenther 1999: 7). The following is a lightly edited version of Lloyd's translation, with punctuation and paragraphing added.

The Lynx and the Anteater

$$
\text { LL.V.6.4344'-4377' }
$$

\section{(Unpublished)}

The Anteater used to be anxious about the Lynx because she felt that the Lynx was handsome. Therefore she took care of the Lynx.

She did not want men to play with the Lynx because she was her heart's child. The Lynx used to be with the Anteater when she was searching for Bushman rice (termite larvae). Therefore, the Anteater did not want the folk to play for her with the Lynx. The people loved the Lynx's nice playing upon the !kummi. The folk loved the Lynx on account of it, for when the Lynx played the !kummi, her !kummi sounded very sweet.

\footnotetext{
${ }^{1}$ In references to the Bleek and Lloyd Archive, LL indicates Lucy Lloyd as the transcriber; the Roman numeral indicates the informant and the Arabic numeral his or her notebook; the page numbers follow. The whole archive may be found at $<$ http://lloydbleekcollection.cs.uct.ac.za $>$.
} 


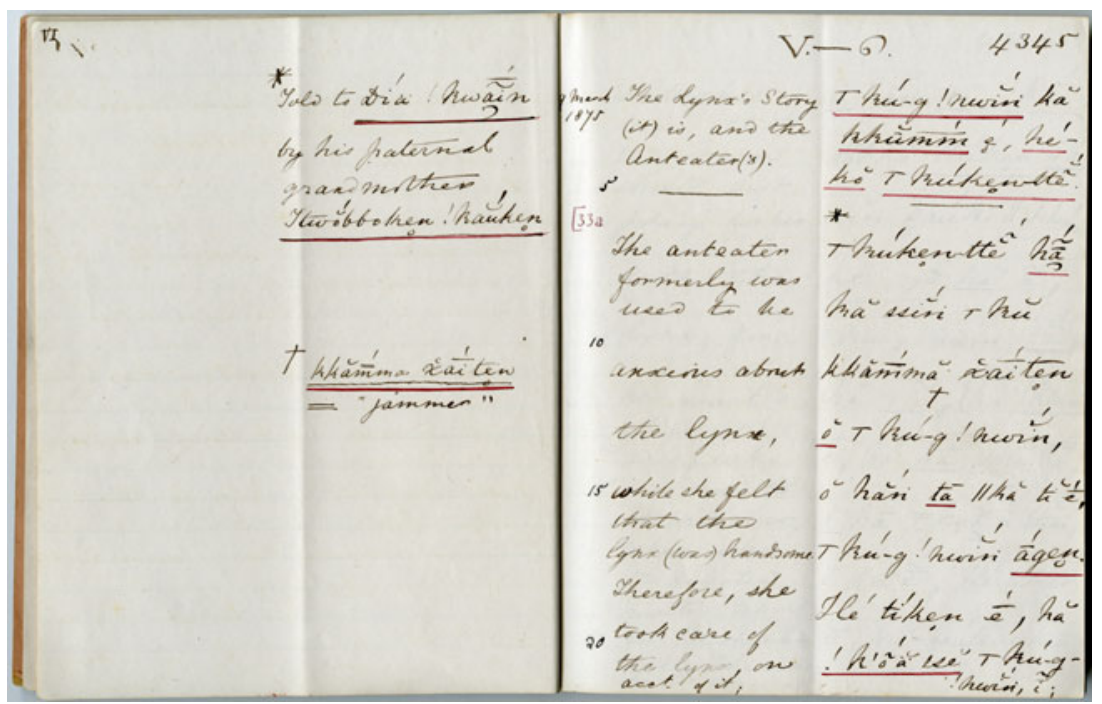

FIgURE 2 The first page of Diä!kwain's tale 'The Lynx and the Anteater' (LL.V.6.4344'-4345).

Therefore the Anteater used to place her pillow at the end of the !kummi's stick because she wanted the !kummi's sound to enter her ear so that she might listen to how the Lynx played. For the Lynx played the !kummi touchingly. The Anteater did not want the Lynx to leave her because of the Lynx's playing the !kummi. The sweet music was why she did not wish the Lynx to leave her. The Lynx was a small eater.

The Anteater did not wish the Lynx to leave her [the Anteater's] house. She wanted the Lynx to continue to live with her. She was anxious on account of the Lynx. She did not want the Lynx to go away from her. Therefore, she did not wish that people should play with the Lynx.

Therefore she used to listen at night to the Lynx's breathing, as she slept. The Lynx did not seem to lie comfortably. The Anteater heard the !kummi string. And she wondered about it. And she said, 'I seemed to hear the !kummi's vibrating.'

And the Lynx spoke. She told the Anteater that a little stick seemed to have struck along the !kummi's string when she had turned over.

The Anteater said, 'It does not seem as if it was a little stick that struck along the !kummi's string. It seemed as if a person took up the !kummi, because it would have sounded gently if a stick had struck it. It would have sounded gently. It seemed as if a man had taken up the !kummi. The !kummi did not sound just a little; it sounded as if a man had taken it up. Therefore I will first listen to see if it be true that a stick had struck along the !kummi. For it seemed as if harm were coming to the Lynx. Therefore I will listen to find the real truth.'

And the Anteater slept. And people came and stole away the Lynx while the Anteater was asleep.

The Anteater awoke and asked the Lynx whether she would not first play for her at daybreak so that she might listen how the Lynx always played.

She asked, 'Are you fast asleep that you do not answer me? You are always willing to play the !kummi at daybreak. What is the matter with you that you are not willing to play the !kummi today? You used to play the !kummi at daylight. I thought that the !kummi 
had sounded. That is why I have called you in vain, \|kha! [an exclamation]. You must have gone away. I will feel the place that you seem to have gone to.'

And the Anteater went into the earth upon which she lay so that, feeling, she might seek the place to which the Lynx seemed to have gone. She listened and felt the earth. She felt that the earth moved/shook. And the Anteater said, 'The earth seems as if it were soft.'

And the Anteater said that she had distrusted what the Lynx had said about the !kummi's string being struck by a stick. When she had questioned the Lynx, she had told her that a stick had struck along the !kummi's string. Therefore she wondered what thing could have caused a stick to strike along the !kummi during the night. The !kummi was not used to do so. The Lynx must have felt that she intended to act thus. 'That was why she spoke to me about it: she must have felt that she intended to go away.'

And the Anteater said, 'I will first go into the earth at the place where the Lynx was lying down, so that I may feel the earth at it.' And she entered into it. She went along. She was feeling the earth. She felt that it was soft. She said, 'The place now shakes/vibrates.'

And the people with whom the Lynx went said, 'The earth now shakes where we are walking over it. You must look out for a hurru ttwiten [a bird] because it is the Anteater. She wants to cause a sudden disappearance to swallow in the Lynx. She does not go above ground so that we might know when she is near us. For she is a hurru ttwiten. You feel that the earth upon which we are walking moves under our pressure.'

They said, 'When you are at a place where the earth seems soft, you must strike it with a stick because the Anteater wants to cause the Lynx to go in just above her, at the place which leads down, for she is a hhurru ssi ttu-tturriten. The Anteater is the one for whom the earth continues to crumble and fall in at the place where she goes along. Therefore you shall know what is happening on account of it. She is seeking the Lynx. The earth above which I walk moves under our pressure.'

And the earth fell in on account of it. All the people fell into it, and the earth covered them.

And the Anteater took away the Lynx. She took the Lynx back to the house. And she asked why the people had come to take away the Lynx. Did they not know that it was her child, she who was a hhurru ttwiten? The Lynx whom they had intended to take away was her child. All those who had taken away the Lynx died under the earth which had fallen in upon them.

\section{Commentary}

The surface narrative of this tale concerns marriage and parent-child relations. The Anteater does not wish to be parted from her child, the Lynx (caracal). Nevertheless, although the Lynx is 'her heart's child', she distrusts her. At the same time, the Lynx deceives the Anteater in the matter of !kummi playing (a musical instrument used by women; the 'pillow' was probably a resonator, such as a gourd or tortoiseshell (Stow 1905: Figure 9)). She willingly departs with the other people. The Anteater kills the abductors by means of her supernatural abilities: burrowing (the ground 'opened of itself before' her: LL.V.6.4373') and her ability to turn into a bird. What was the social setting for these events?

The Bleek family did not systematically record |Xam social structure, but much about it can be inferred from the informants' narratives and biographies. By contrast, twentieth-century ethnographers working with the various Kalahari groups have studied it in depth (Marshall 1976: 168-75; Silberbauer 1981: 149-59; Wilmsen 1989: 181-3; Lee 1993: 79-88; Valiente-Noailles 1993: 99-104). Mathias Guenther (1999: 30), for example, found that San marriage and postmarriage residence rules are 'as variable as they are flexible among the 
Bushman groups of southern Africa'. I therefore conclude that |Xam marriage customs were comparable to, rather than identical with, those among the more recent Kalahari groups.

Generally, San marriages were, and in some areas still are, arranged when the boys and girls were young, frequently some years before a girl's first menstruation, and consummated subsequently. A 1950s Ju|'hoan man was required to live with, and hunt for, his wife's family until three children were born or his debt was considered settled for other reasons. At the completion of bride service he was free to return with his bride and children to his own people. If a husband died after the couple had moved to his camp, the widow usually went back to her own people.

Drawing on these nineteenth- and twentieth-century sources, we can assume that the |Xam practised bride service, though not rigidly. In some cases, the practice led to tensions when a bride was reluctant to leave her own family and go with her husband. A note to a long |Xam account of an accidental death on the hunting ground (Lewis-Williams 2000: 52-77) explains that 'the widow, had long wanted to remain at her father; but her husband thought that they should go to another place' (LL.II.13.1290'). Indeed, tensions between virilocal and uxorilocal marriage underlie a number of $\mid$ Xam folktales, including the present one and the two that follow. Biesele (1993: 165) found that 'the tensions of bride-service and marital residence' were 'strongly etched' in some Ju|'hoansi narratives. Why should this be so?

Edwin Wilmsen (1989), among others, has analysed the relationship between marriage relations and land rights. He emphasizes the point that marriage between Ju|'hoan families establishes affinal relations that open up access to a range of waterholes and resources. These relations ensure that 'one will never go hungry' (Lee 1993: 88). |Xam territories (!xoe), broadly comparable to Jul'hoan n!ore, were centred on a waterhole (McGranaghan 2012: 439-40). Marriage and marriage failure are thus important for many people, not just for the married couple (Keenan 1981). The access to resources that the Lynx's marriage would have opened up would have been valuable for the Anteater's band, but she nevertheless seems to have deemed the cost of losing her daughter and, especially, her music too high.

Of interest to our present enquiry is Lorna Marshall's (1976: 266) description of 'marriage by capture'. Richard Lee (1993: 82-4), too, writes of a 'marriage-bycapture' ceremony, which features 'the mock carrying off of the girl from her parents' hut to a specially built marriage hut'. He adds that the ceremony expresses 'real conflict between husband and wife and between children and parents' - as we see in the |Xam Anteater and Lynx tale. Although Ju|'hoan men did not 'capture' brides when the Marshalls were living with them, the subject often came up in conversation: 'Nowadays the idea of capturing wives appears to be enjoyed by men as a fantasy' (Marshall 1976: 266; see also Barnard 1992: 51; Lee 1993: 83, 92). Though not explicitly stated, the notion, or 'fantasy', of marriage by capture seems to underlie the tale of the Anteater and the Lynx.

Also not explicitly stated is the setting of this tale in the Primal Time, or First Order (Biesele 1993; Guenther 1999: 66ff.; Lewis-Williams and Pearce 2004a: 164-6; Wessels 2010). It was then that the people of the Early Race were animals, and animals were people. The Primal Time was 'removed' rather than just temporally remote. But it sometimes spilled over into the present dispensation in unpredictable ways: 'This confounding of past and present, and myth and reality confers on 
the present order an abiding aura of ambiguity' (Guenther 1999: 66) that expresses itself in numerous, often subtle, ways, not only in myths but also in daily life. For instance, traces of humanity can still be discerned in the physiology of some animals (ibid.: 74-5). In practice, it is not always easy to tell if a |Xam tale relates to the Primal Time or to the present (Brown 1998: 54). I suspect that in many instances the Bleek family's narrators did not specify the Primal Time context of a myth because they assumed that their auditors would realize this or that it simply did not matter.

The Primal Time setting of the tale about the Anteater and the Lynx directs attention to its supernatural elements; there is more to the story than the clandestine abduction of a musical child. Writing of the Primal Time, Guenther discerns an important link between it and San 'trance dancers' (shamans or medicine people) (Bleek 1933; 1935; 1936; Lewis-Williams 1981: 75-101; Lewis-Williams and Pearce 2004a: 81-99): 'Like the beings of the First Order in mythic time, the dancers of today may shift their ontological state, crossing back and forth between boundaries that separate them from spirit and animal beings, from life and death' (Guenther 1999: 191).

Referring to San songs, Biesele makes points about phrasing that are fundamental to any understanding of such transitions and ambiguities, especially in myths or songs, but also in daily life: '[I]t is extremely hard to understand what is going on in the singing ... In order for us to experience the songs in anything approaching such meaningfulness, we need a great deal of background' (Biesele 1975: 176). An example that she gives helps us to understand a key point: who is performing the abduction in the tale about the Anteater and the Lynx?

[W]ords in Zhũ|twã songs are often altered by phonemic transformation and by syllable elision. Furthermore, the beginning of a phrase may be uttered and broken off, but the entire phrase must nevertheless be inferred from context. An example is Jack's $A$ tshesi ba ku kwe ...? Which implies $A$ tshesi ba ku kwe guni mi? (What things thus [hound me]?), a phrase commonly heard as a complaint in daily life. A tshesĩ itself is metaphorical. 'What things?' it asks: its referent is not an open question but specifically the Ilgaũwasi, the ghosts or spirits of the dead. It is safer, in general, not to name them. Thus the sentence functions for a member of the culture as a rhetorical question so obvious that no answer is required. (Biesele 1975: 176-7)

Seen in this context, the nameless 'people' constitute a nugget, one that could not be identified without deep cultural knowledge. They who come at night to steal away the Lynx are probably malevolent shamans, who may also be spirits of the dead (the distinction is not always clear). San listeners would have simply accepted that that was who they were. It was safer not to speak freely of their true identity.

Xam shamans - !gi:ten - were 'full of' !gi:, supernatural potency (LewisWilliams 1981; 1992; 2015a). Potency has many manifestations, including certain large game animals, rain, thunder, lightning, meteors, finger pointing and snapping, whirlwinds, burning horn, aromatic herbs (buchu), scent, honey, fire, dancing, music, rock paintings, and so forth (Biesele 1996: 142). Each of these may be a nugget when it appears in San folklore: 'The verbs and nouns of potency are inextricably embedded in the metaphors of narrative and it is only ethnographic context - or, if we are fortunate, narrators' commentary - which can cause them to stand out as figures against ground' (ibid.: 142-3). 
Ju|'hoansi shamans are known as $n \mid$ om k"ausi (owners of potency) (Katz 1982; Biesele 1993; Guenther 1999). At 'medicine dances' during which they enter an altered state of consciousness, and also in more restricted social contexts, they cross over to the spirit realm. Their benevolent or malevolent powers are believed to continue after death. The notion that such 'sorcerers' could carry off people recurs in the Bleek and Lloyd texts. For instance, when a sorceress was healing Diä!kwain, she told him that 'other sorcerors [sic] had been seizing [him], they wanted to take [him] with them' (Bleek 1935: 20). Abduction by supernatural beings is part of San thought.

The inter-realm fluidity achieved by trance dancers is not distinct from myth. There are parallels between myth and dance: the realms interact in both (Guenther 1999: 191). This is evident in the identities of the Anteater and the Lynx. Today, the Anteater is best known to researchers for the 'Anteater's Laws' that govern marriage. In other parts of the texts, the Anteater behaves in the manner of a shaman, or even as |Kaggen (himself the ur-shaman; LewisWilliams and Pearce 2004a: 112-13). In a Maloti San myth, |Kaggen (Cagn) travels underground: he goes underground and comes up three times, finally emerging transformed into 'a large bull eland' (Orpen 1874: 8; McGranaghan et al. 2013: 159). In the |Xam tale, the Anteater also transforms her species and becomes a little bird that dives into the ground and travels under it. Mark McGranaghan (personal communication) suggests that the bird given here as hurru-twiten is a variant of koro-twiten, the ant-eating chat (Myrmecocichla formicivora). Their nests and roost sites are subterranean, and they use abandoned anteater burrows. The combination of flight and underground travel is characteristic of San shamans' behaviour (Bleek 1935: 18-19; Hollmann 2004: 224-7). In her zoological form, the Anteater travels underground, as indeed anteaters do in their burrows, though in the myth the ground 'opened of itself' (LL.V.6.4373'). All in all, the Anteater may be seen as an anomalous creature that lives on and under ground, two components of the San three-tiered cosmos, a concept that embraces fluidity between spiritual and diurnal experiences (Lewis-Williams and Pearce 2004a: 51-5).

Another narrative records how the Anteater's and the Lynx's nocturnal habits came about: 'The Anteater said: "Destruction/curse you there, you shall be a Lynx who walks about at night." The Lynx also said: "Curse/destruction [on] you there, you become an Anteater who walks about at night"" (LL.VIII.29.8600-8601). The phrase 'to walk about at night' is a nugget that invokes San beliefs about shamans. A characteristic of malevolent shamans was that they prowled at night seeking people to abduct or harm. A |Xam informant made the point explicitly: 'For it is the sorceror's [sic] custom to walk about at night' (LL.V.19.5501). These shamans often did their nocturnal prowling in the form of lions (Bleek 1935: 2; Katz 1982: 227; Biesele 1993: 111; Marshall 1999: 187; Marshall Thomas 2003: 74). Like shamans, lions are nocturnal and diurnal.

A specific case concerns !Nuin-|kúïten, a |Xam man who died and became a benign spirit that 'goes by night' to protect his people from nocturnal marauding shamans (Bleek 1936: 132). After he died, !Nuin-|kúiten wanted to take another man, Xã:ä-tin, with him to the spirit world so that he could teach him rainmaking songs (Bleek 1936: 133; Lewis-Williams 2015a: 183-200). The antagonistic or, in the case of !Nuin-|kúiten, more benign abduction of living people to the spirit 
realm, especially those with shamanistic ability, was part of |Xam belief (LL. V.19.5485).

A central question remains. It takes us to the heart of this tale. Why did the other 'people' want to abduct the Lynx? To answer this question, we must go beyond the surface narrative of marriage by capture or conflict between virilocal and uxorilocal residence. Certainly, the Lynx was the Anteater's daughter, whom she loved, but the text repeatedly emphasizes the child's beautiful music. For the San, music and singing have complex associations. For instance, Biesele met a Ju|'hoan man who entered a trance by playing a thumb piano, normally an instrument for reflection or entertainment (Biesele 1975). Nevertheless, although San do not entertain a strict separation between 'sacred' and 'profane', some music is considered recreational while other music is imbued with shamans' supernatural potency and facilitates their entry into the spirit realm. The potency that is activated at a medicine dance resides not only in the shamans themselves but also in the dance songs that the women sing and the rhythms they clap (Marshall 1969: 350; 1999: 74-82; Katz 1982: 122-4; Biesele 1993: 74). The singing of, specifically, rainmaking songs and the playing of music were techniques used by |Xam !khwa-ka!gi:ten (shamans of the rain) (Bleek 1933; Lewis-Williams 2015a: 187). For instance, a |Xam rainmaker named |Kãũnũ played a 'musical bow', which recalls the Lynx's !kummi. He 'used to strike the bow-string, and then the clouds came up ... it rained there, poured down until the sun set' (Bleek 1933: 390).

An important detail is that the music that the Lynx played at dawn was deemed special. A Kalahari medicine dance may continue all night, but at dawn the dancing and singing are particularly intense, and the 'medicine music' is considered to be especially strong (Marshall 1969: 362). Lloyd recorded a comparable |Xam dance: 'The men are those who dance, while the women sit down [and] clap their hands.' The dance lasted until dawn: '[T]he sun shines upon the backs of their heads (upon "the holes above the nape of their neck")' (Bleek and Lloyd 1911: 355-7). The Ju|'hoansi speak of a sensitive 'hole' $(n \| a u)$ in the nape of the neck through which shamans expel sickness they have removed from people (Biesele 1993: 75; Marshall 1999: 60).

Striking the ground with a stick was another way of contacting spirits. |Xam women beat the ground with a digging stick fitted with a bored stone to call upon spirit people (Bleek 1935: 35, 36, 41). In another instance, we read: 'And when mother struck the digging-stick stone on the ground, she said, "The backs of your heads are here, you who are spirit people have turned your backs on me here" (ibid.: 42). There is no mention in the Anteater tale of a bored stone being on the stick, but that may be implied.

Much more could be said about this tale: certainly, there is more to it than an entertaining story about abduction. When we take into account the euphemistic use of 'people', the role of music, especially at dawn, the Anteater's transformation into a bird and her underground travel, and the striking of the ground with a stick, it seems that the tale has a 'spiritual' dimension: nameless spirits were abducting the Lynx to gain possession of the power that resided in her music. The Lynx was protecting the Anteater's camp by means of her music, and the antagonistic spirits wanted that music. Medicine dances and their music are believed to please and pacify the malevolent spirits of the dead (England 1968: 400). Indeed, supernatural conflict over the possession of potency is a recurring theme in San myth and thought (Lewis-Williams 2015a). 


\section{Another tale, another theme}

A comparable tale, 'The Anteater's story', was provided by a female informant, !Kweiten ta \|ken (Rachel). Wife of the informant |A!kunta, she was with the Bleek family for only seven months in 1874-75. Her most useful comments pertain to women, especially girls at puberty (Deacon 1996: 35-6).

Guenther (1989: 83-5) gives the informant \|Kabbo's variant of the tale and writes of the 'ontological nature' of the animals becoming blurred (ibid.: 83). He also refers to |Han $\neq$ kass'o's 'superbly told rendition'. Roger Hewitt (2008: 93-6) gives a summary of the variants of the myths that present the Anteater as a creator. They proclaim the Anteater's laws concerning the change-over from the Primal Time to the present dispensation. Michael Wessels (2010: 255) identifies sexual and related maternal issues that link this narrative to other tales.

Space restrictions demand that I give only a summary of !Kweiten ta \|ken's variant (Figure 3). For the full tale, see LL.VI.1.3916-3929. In it, the Anteater plays a strikingly contrary role to that seen in 'The Lynx and the Anteater'. In her performance for Lloyd, !Kweiten ta $\|$ ken repeated the last part of the tale.

The Anteater steals away the Springbok's daughter. She then looks after and feeds the young Springbok. The mother Springbok sends the Lynx, here a man, to recover the child because he can move stealthily. He does so while the Anteater is out collecting 'Bushman rice'. He returns the young Springbok to her camp. When the Partridge tells the Anteater what has happened, the Anteater travels underground to her now-deserted camp. Again going underground, she follows the young Springbok and the Lynx on their way back to the Springbok camp. The Lynx feels the earth heaving under their feet, and he then knocks the Anteater down with a club and kills her.

\section{Commentary}

Because the Anteater is female, there does not seem to be any reference to marriage by capture or to the residence of a bride, though echoes of other tales may have been evoked in |Xam listeners' minds. Be that as it may, what is important for our present purposes is that the informant made it clear that the young Springbok had reached puberty: 'The Lynx went to tell the mother Springbok that the young Springbok had grown up' (LL.VI.1.3917). The word used here, !kouken tten ya, means that she had had her 'first menstruation' (Bleek 1956: 445). This nugget situates the whole tale.

Puberty, a highly significant time in a San girl's life, was widely marked by the Eland Bull dance (Bleek 1928: 23; Lewis-Williams 1981: 41-53; Guenther 1999: 153-4, 165-7; Marshall 1999: 197-9). As Guenther (1999: 165) states: '[T]he female initiation rite was and is basically the same across Bushman tribes, from the |Xam of the Cape to the !Kõ, Nharo, and G|wi.' What then is the significance of girls' puberty?

For the Jul'hoansi, the girl is a 'good thing'. In the 1970s, an old Jul'hoan woman told me: 'The Eland Bull dance is danced because the eland is a good thing and has much fat. And the girl is also a good thing and she is all fat; therefore they are called the same thing.' She added that the Eland Bull dance benefits the girl and, moreover, ensures that 'all will go well with the land and that rain will fall' (Lewis-Williams 1981: 50). The girl is thus a powerful force for good not just for herself, but for the whole community. 


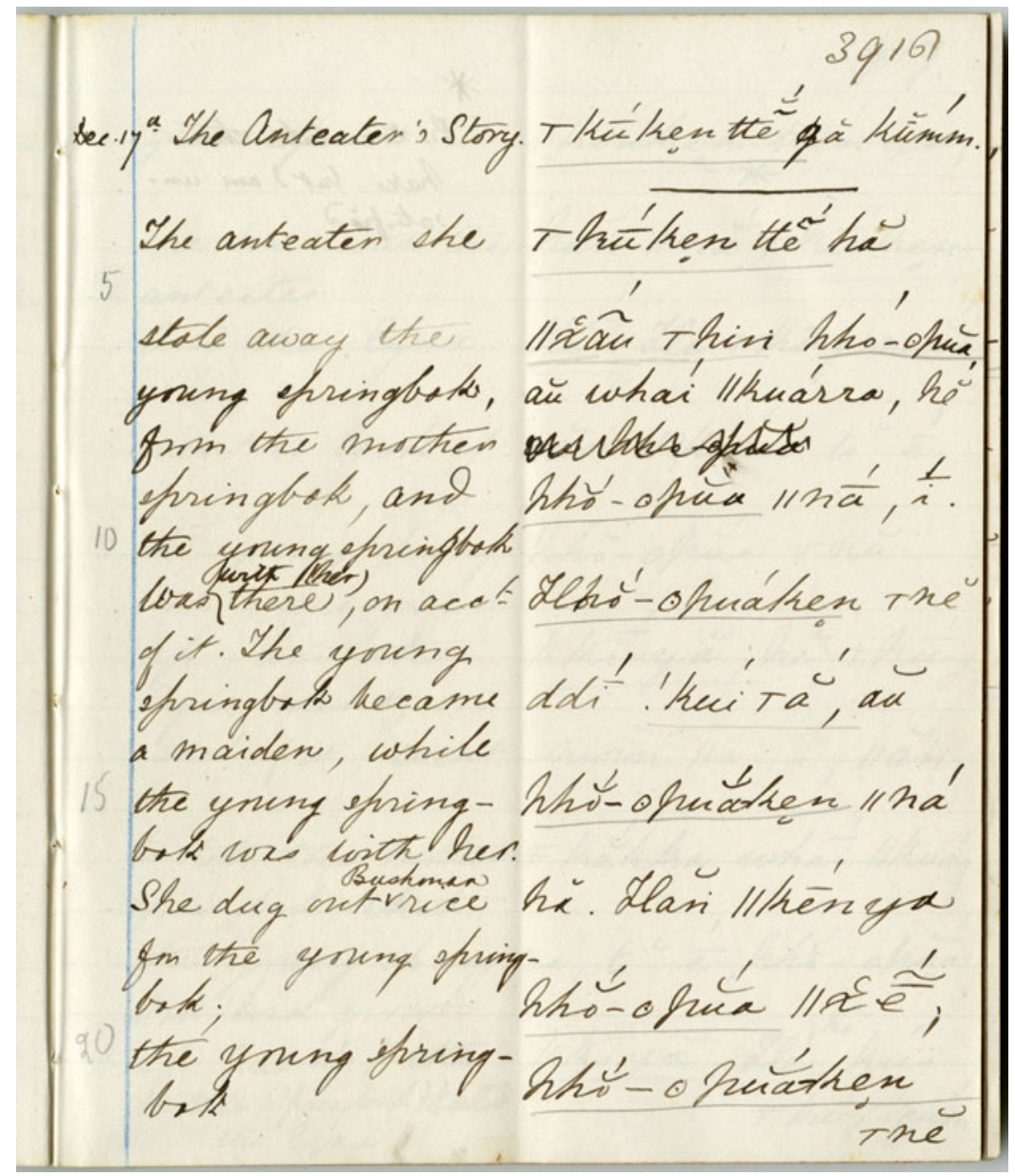

FIGURE 3 The start of !Kweiten ta \|ken's tale 'The Anteater's story' (L.VI.1.3916). The facing page, not shown here, is blank.

Comparably, the |Xam believed that a girl at puberty, a 'new maiden' (!kwi-|a $\| k a: \eta)$, 'has the rain's magic power' (!khwa ka |koödde, LL.V.13.4989). 'New maidens' should therefore be respected and, in turn, they should respect the rain (McGranaghan 2012: 191): 'When a maiden takes care of her people, the rain will not become angry with her people' (LL.V.13.4997-4998). Because a 'new maiden' has this potency, she must take care not to behave disrespectfully to her elders; if she does, the rain will become 'angry'.

In the tale 'The Lynx and the Anteater' there is no explicit mention of girls' puberty. It may, however, be implied. The sentence 'Therefore, she did not wish that people should play with the Lynx' may mean more than play music. In this instance, !k' hwerre-ja, the word translated as 'play with', may mean disrespect or 'tease, annoy, attack' (Bleek 1956: 610; McGranaghan personal 
communication). If this is so, and if |Xam listeners would have accepted that as obvious, we are dealing with what would have been seen as a dangerous situation. Disrespecting 'new maidens' could lead to disaster for all the people in a camp.

In sum, a malevolent Anteater, who travels underground, abducts a 'new maiden', one who, by means of her 'magic power', afforded rain and protection for her band, as did the Lynx's music in the previously discussed tale. Conflict over the possession of potency and its social effects recurs in my third tale.

\section{Fighting with lightning}

The informant $\mid$ Han $\neq$ kass'o said that he had the tale ' $\neq$ Kágára and !Hãũnu, who fought each other with lightning' from his maternal grandmother, $\neq \mathrm{Kammi}$, and, after her death, from his mother, |Xabbi-an (LL.VIII.30.8636'-8648). He was with the Bleek family for nearly two years from January 1878 to December 1879 (Deacon 1996: 30). Lloyd recorded the tale on 24-25 July 1879 (Figure 4). |Han $\neq$ kass'o had access to traditions antedating the arrival of white settlers, for Lloyd records that his father, Ssounni, 'possessed no Dutch name, because he died before the Boers were in that part of the country' (LL.VIII.1.6052; LewisWilliams 1981: 27). Because the tale has been published (Bleek and Lloyd 1911: 112-19; Biesele 1993: 3-5; 1996: 143-4), I give only a summary:

A young woman went to live with her new husband, !Hãũnu. We can assume that she was unhappy in her affines' camp. Her elder brother, $\neq$ Kágára, therefore took her away from !Hãũnu and brought her back to her own camp. On the way back, !Hãũnu pursued $\neq$ Kágára and fought with him. They were both shamans. !Hãũnu bled profusely from the nose and then hurled lightning at $\neq$ Kágára. They hurled lightning at one another. Finally, $\neq$ Kágára hurled black lightning at !Hãũnu, who then returned to his camp to die. $\neq$ Kágára, too, suffered, but he succeeded in getting his sister back. He rubbed his sister and himself with healing aromatic herbs.

\section{Commentary}

Biesele (1996: 145) found that '[t]here is much ... in this |Xam fragment which can be elucidated by reference to Jul'hoan oral tradition and ethnography, despite the intervening years, distances, and linguistic differences'. This is another case in which the interlocking mosaic of San ethnography can be usefully explored.

The men fight over possession of $\neq$ Kágára's young sister, whom !Hãũnu had married. There is no mention of puberty. Instead, the protagonists are spoken of as brothers-in-law. Possibly, !Hãũnu should have performed more bride service at his bride's camp, or the marriage may have failed for some other reason. Either way, 'affinal symbolic conflict' is a recurrent theme in San folklore (Biesele 1996: 145).

Nevertheless, if we note $\mid$ Han $\neq$ kass'o's comments on the tale, an encapsulating theme emerges. At the outset, he situated the events by saying explicitly that !Hãũnu was a rainmaker (LL.VIII.30.8637'; Biesele (1993: 5) omits this defining point). Indeed, both men were shamans: |Han $\neq$ kass'o said that \#Kágára was 'a little bird' (LL.VIII.30.8637'). This nugget is more than a reference to the Primal Time when animals were people. As we have seen, |Xam 


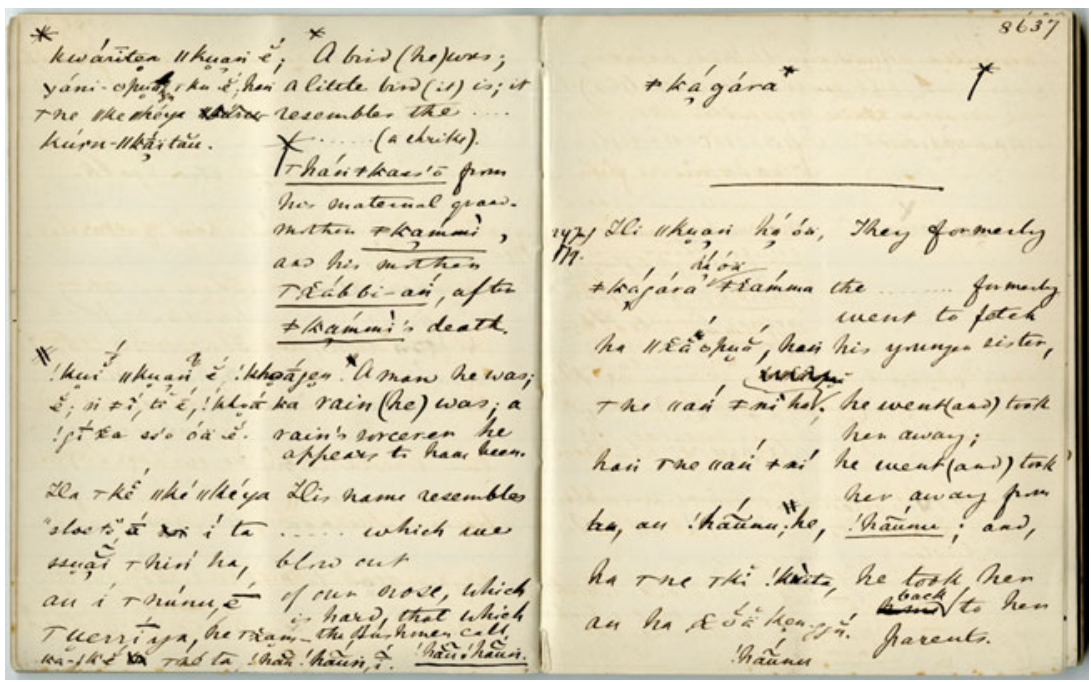

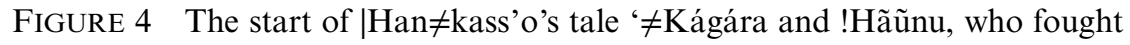
each other with lightning' (L.VIII.30.8636'-8637).

shamans were believed to be able to turn themselves into birds (Bleek 1935: 18-19; LL.V.8.4701'; LL.V.14.5055-78). It is therefore significant that |Han $\neq$ kass'o also said that !Hãunu's name 'resembles "sloete", which we blow out of our nose' (LL.VIII.30.8636') because mucus runs from the noses of dancing shamans (Marshall 1999: 87). |Xam names are often meaningful (Lewis-Williams 2013b; McGranaghan 2015).

During the fight, !Hãũnu 'sneezed ... blood poured out of his nostrils'. This nugget also points to |Xam shamanism. In both texts and rock art, nasal bleeding is an oft-encountered reference to a shaman's trance state (Lewis-Williams 1981: 78ff.; Lewis-Williams and Pearce 2004a; cf. Marshall 1969: 374). Indeed, the word 'nose', |nũnu, held much meaning for the |Xam. For instance, Diä!kwain described shamans as 'the folk who possess their noses (the sorcerers)' (LL.V.13.5020, Lloyd's parenthesis). Lloyd transcribed another of his statements as follows: 'The sorcerers said that they intended to take away my nose / "snoring"-power, that which I killed people with' (LL.V.4.4180). She seems to have deleted the puzzling word 'nose' and inserted "'snoring"-power' as a result of discussion with

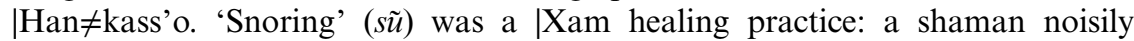
sniffed sickness out of a patient. 'Snoring' and sneezing leading to epistaxis also occur in another |Xam tale: blood falls from Mother Dassie's nose after a sneeze (Bleek 1924: 47). Sometimes |Xam shamans rubbed their nasal blood on patients in the expectation that it would cure them. The nose also allowed shamans to sense things from afar: 'A sorcerer smells like a dog, he smells far off, smells what has been happening there, while he sleeps' (LL.V.19.5504'). The sneezing and nasal bleeding event thus places the conflict in the realm of shamans' trance experience.

Lightning is another nugget. Marshall (1962: 244) found that the Jul'hoansi considered lightning a 'death thing' that the spirits of the dead used to kill 
people. For the Xam, it was a manifestation of potency and also invoked beliefs about 'new maidens'. A girl at puberty could snap her fingers and thus cause people to be struck by lightning: a disobedient 'new maiden' who had this power 'kept snapping her fingers at them ... Then the rain became angry with her, the rain gathered its clouds and lightened on [all the people]' (Bleek 1933: 298-9). In |Han $\neq$ kass'o's tale, it is shamans, not 'new maidens', who exercise this power (cf. Biesele 1993: 105). During the fight, !Hãũnu retaliates by directing lightning at $\neq$ Kágára. But $\neq$ Kágára 'fended him quickly off' and responds by hurling lightning back at him. Finally, when $\neq$ Kágára resorts to 'black lightning', !Hãũnu is vanquished and 'whisked ... up' and carried 'to a little distance'. At this time, 'the clouds were thick'. Thanks to lightning, the girl and her belongings are safely restored to her home.

A particularly allusive nugget occurs at the end of the tale: its connotations again interconnect girls at puberty, rain and shamans. $\neq$ Kágára rubbed himself and his sister with $s \tilde{a}$, aromatic healing herbs widely known in Southern Africa by the Khoekhoe word buchu. The informant's fourfold repetition of the word sã may suggest that much buchu was used. On the other hand, |Han $\neq$ kass'o may have concluded the narrative with a chant or song. Buchu had wide associations for the |Xam, including potency. For instance, a dangerous rain-animal could be calmed by having buchu rubbed on it (Bleek and Lloyd 1911: 195; Bleek 1933: 382). The same idea is seen in the practice of girls at puberty scattering ground-up buchu on the surface of 'new water' (!khwa: ||ka:y) in ponds because 'the rain loves buchu very much' (Bleek 1933: 300). The word \|ka: $\eta$ means 'new, fresh', as in !kwi|a \|ka:y, 'new maiden' (Bleek 1956: 556). Freshly fallen 'new rain' was to be respected; it was high in potency, like the new maiden herself, who possessed 'the rain's magic power' (LL.V.13.4989). The Ju|'hoansi hold comparable beliefs. I was told that recently fallen rain has very strong potency $(n \mid o m)$, as does a girl at puberty (Lewis-Williams 1981: 52). The potency of new maidens and rain are thus linked through buchu.

In addition, Lloyd was told that, in the 'snoring' process, a shaman may become frenzied, having sniffed a lion out of a patient and into his own body. People therefore gave him buchu to smell 'and he sneezes the lion out' (Bleek 1935: 2). Of this instance, Biesele (1996: 145) notes: 'The detail of rubbing with buchu is another instance of potency transfer.'

When a shaman returned from an out-of-body trance journey, he was considered to be in a dangerous condition: he 'trembles' and his 'vertebral artery has risen up' (LL.V.3.4121'). 'All his veins are standing up' (Bleek 1935: 23-4). If he is given buchu to smell, his veins lie down. If this were not done he could 'become a beast-of-prey' (ibid.) and bite people. In |Han $\neq$ kass'o's narrative, $\neq$ Kágára has returned from a dangerous shamanic journey.

\section{Plot, subplot and nuggets}

All in all, an obliquely signalled subplot in each of the three |Xam abduction tales concerns conflict in a supernatural realm over possession of protective potency or the use of potency in supernatural combat and defence. Although not claiming that this is the only concern of San mythology, I contend that the restoration of 
appropriate social relations, and the protection that potency can facilitate if properly controlled, are central themes that may not be immediately apparent in the narrative itself.

Readings of this kind have social implications. The protagonists in supernatural conflicts in San folklore are shamans or spirits of the dead - those who possess potency. This is the case either directly, as in the lightning fight, or indirectly through the performance of actions that are closely associated with shamans. The social impact of performances of the tales was thus to remind people of the importance of shamans to the community at large and to emphasize their vital role in conflict resolution. In what is an ostensibly egalitarian society, San shamans were (and still are) respected, even feared. Their authority is spiritual rather than structural, although their 'symbolic labour' renovates economic social relations (Lewis-Williams 1982; Lewis-Williams and Pearce 2004a: 196201; 2004b; Lewis-Williams 2015a: 69, 204-6).

Finally, we must allow that nuggets such as those I have identified and analysed make the unravelling of San tales more complex than approaches limited to narrative structures: subtly, nuggets lead from one area of belief and experience to another. We find ourselves caught in a linguistic web, the complexity of which is cumulatively revealed as we analyse tale after tale. This is an ongoing task, of which this article is a part: one tale does not hold all the answers. By focusing in this way on details of specific performances rather than synoptically emphasizing elements of manifest plots, we are able to hear something of what a |Xam audience may have heard - even allowing for marked differences between an indigenous context and a Victorian home in Cape Town. By unpacking nuggets with 'enormous ramifications' (Biesele 1996: 145), we are able to compensate at least in part for the loss of an authentic |Xam setting and glimpse indigenous meanings.

In the past, this web of meanings extended to the making of much Southern African San rock art. Like myths, San rock art panels are peppered with painted nuggets (for example, nasal bleeding, distinctive trance dance postures): the images refer to much more than simple day-to-day events, such as hunting. Contrary to earlier narrative explanations of the art, the images deal principally with the integration of material and supernatural realms, as it is brought about by shamans, some of whom were probably painters. This integration is made palpable in certain images that were in themselves reservoirs of potency on which all people could draw (for example, depictions of eland made partly with eland blood). The management and exercise of potency by individual shamans thus extended across domains of communication and created an all-embracing semantic web (Lewis-Williams 2010; Lewis-Williams and Pearce 2004a; Lewis-Williams and Challis 2011).

The notion of nuggets can be usefully employed in the study of other African folklore - and indeed beyond the continent as well. But researchers in other areas often have to deal only with summaries of tales rather than with the verbatim, phonetic San transcriptions to which researchers are so fortunate to have access. Instances in which only summary and often synoptic versions of tales are available pose serious problems for researchers who may wish to go beyond structural studies of narratives. They may, however, note that even in summaries some nuggets do manage to survive translation, as was the case with Orpen's record of Qing's tales (1874). But identification of them and their significances 
will always depend on the researchers' deep knowledge of the people's cultural milieu and its internal patterns of associations. It is the reading of general ethnographies that alerts researchers to potential nuggets that may appear in mythical narratives. One thing that San folklore has shown us is that tales should be approached hand in hand with a deep exploration of their cultural setting, even if original language transcriptions are not available.

\section{Acknowledgements}

I thank those who commented on drafts of this article: Megan Biesele, Sam Challis, Jamie Hampson, Mark McGranaghan, David Pearce, Jeremy Hollmann, David Witelson and three anonymous referees. The librarian at Jagger Library, University of Cape Town kindly gave permission to use Figures 2, 3 and 4. David Pearce prepared Figure 1. The University of the Witwatersrand Rock Art Research Institute has provided a stimulating centre for research. This work is supported by a National Research Foundation rating grant.

\section{References}

Adhikari, M. (2010) The Anatomy of a South African Genocide. Cape Town: University of Cape Town Press.

Bank, A. (2006) Bushmen in a Victorian World: the remarkable story of the BleekLloyd Collection of Bushman folklore. Cape Town: Double Storey, Juta.

Barnard, A. (1992) Hunters and Herders of Southern Africa: a comparative ethnography of the Khoisan peoples. Cambridge: Cambridge University Press.

Barnard, A. (2007) Anthropology and the Bushman. Oxford: Berg.

Barnard, A. (2013) 'Cognitive and social aspects of language origins' in C. Lefebvre, B. Comrie and H. Cohen (eds), New Perspectives on the Origins of Language. Amsterdam: John Benjamins Publishing Company.

Biesele, M. (1975) 'Song texts by the Master of Tricks: Kalahari San thumb piano music', Botswana Notes and Records 7: 171-88.

Biesele, M. (1993) Women Like Meat: the folklore and foraging ideology of the Kalahari Ju|'hoan. Johannesburg: Witwatersrand University Press.

Biesele, M. (1996) "'He stealthily lightened at his brother-in-law" (and thunder echoes in Bushman oral tradition a century later)' in J. Deacon and T. A. Dowson (eds), Voices from the Past: |Xam Bushmen and the Bleek and Lloyd Collection. Johannesburg: Witwatersrand University Press.

Bleek, D. F. (1924) The Mantis and His Friends. Cape Town: Maskew Miller.

Bleek, D. F. (1928) The Naron: a Bushman tribe of the central Kalahari. Cambridge: Cambridge University Press.

Bleek, D. F. (1933) 'Customs and beliefs of the |Xam Bushmen. Part V: The rain', 'Part VI: Rain-making', Bantu Studies 7: 297-312, 375-92.

Bleek, D. F. (1935) 'Beliefs and customs of the |Xam Bushmen. Part VII: Sorcerors', Bantu Studies 9: 1-47.

Bleek, D. F. (1936) 'Customs and beliefs of the |Xam Bushmen. Part VIII: More about sorcerors and charms', Bantu Studies 10: 131-62.

Bleek, D. F. (1956) A Bushman Dictionary. New Haven CT: American Oriental Society. 
Bleek, W. H. I. (1873) Report Concerning Bushman Researches by W. H. I. Bleek, PH.D. Cape Town: House of Assembly.

Bleek, W. H. I. (1875) Second Report Concerning Bushman Researchers, with a Short Account of the Bushman Native Literature Collected. Cape Town: Government Printer.

Bleek, W. H. I. and L. C. Lloyd (1911) Specimens of Bushman Folklore. London: George Allen.

Brown, D. (1998) Voicing the Text: South African oral poetry and performance. Cape Town: Oxford University Press.

Deacon, J. (1986) "“My place is the Bitterpits": the home territory of Bleek and Lloyd's |Xam San informants', African Studies 45: 135-55.

Deacon, J. (1988) 'The power of a place in understanding southern San rock engravings', World Archaeology 20: 129-40.

Deacon, J. (1996) '|The |Xam informants' in J. Deacon and T. A. Dowson (eds), Voices from the Past: |Xam Bushmen and the Bleek and Lloyd Collection. Johannesburg: Witwatersrand University Press.

Deacon, J. and T. A. Dowson (eds) (1996) Voices from the Past: |Xam Bushmen and the Bleek and Lloyd Collection. Johannesburg: Witwatersrand University Press.

Deacon, J. and P. Skotnes (eds) (2014) The Courage of \|kabbo: celebrating the 100th anniversary of the publication of Specimens of Bushman Folklore. Cape Town: UCT Press.

England, N. (1968) 'Music among the Ju/wa-si of South West Africa and Botswana'. PhD thesis, Harvard University.

Geertz, C. (1988). Works and Lives: the anthropologist as author. Stanford CA: Stanford University Press.

Guenther, M. (1989) Bushman Folktales: oral traditions of the Nharo of Botswana and the |Xam of the Cape. Stuttgart: Franz Steiner Verlag.

Guenther, M. (1996) 'Attempting to contextualise |Xam oral tradition' in J. Deacon and T. A. Dowson (eds), Voices from the Past: |Xam Bushmen and the Bleek and Lloyd Collection. Johannesburg: Witwatersrand University Press.

Guenther, M. (1999) Tricksters and Trancers: Bushman religion and society. Bloomington IN: Indiana University Press.

Hewitt, R. (2008) Structure, Meaning and Ritual in the Narratives of the Southern San. Johannesburg: Witwatersrand University Press.

Hollmann, J. C. (ed.) (2004) Customs and Beliefs of the |Xam Bushmen. Johannesburg: Witwatersrand University Press.

Katz, R. (1982) Boiling Energy: community healing among the Kalahari San. Cambridge MA: Harvard University Press.

Keenan, J. (1981) 'The concept of the mode of production in hunter-gatherer societies' in J. S. Kahn and J. R. Llobera (eds), The Anthropology of Pre-capitalist Societies. London: Macmillan.

Kirk, G. S. (1974) The Nature of Greek Myths. Harmondsworth: Penguin.

Lee, R. B. (1979) The !Kung San: men, women, and work in a foraging society. Cambridge: Cambridge University Press.

Lee, R. B. (1993) The Dobe Ju|'hoansi. New York NY: Harcourt Brace.

Lévi-Strauss, C. (1961) A World on the Wane. New York NY: Criterion Books.

Lewis-Williams, J. D. (1980) 'Ethnography and iconography: aspects of southern San thought and art', Man (N.S.) 15: 467-82. 
Lewis-Williams, J. D. (1981) Believing and Seeing: symbolic meanings in southern San rock paintings. London: Academic Press.

Lewis-Williams, J. D. (1982) 'The economic and social context of southern San rock art', Current Anthropology 23: 429-49.

Lewis-Williams, J. D. (1992) 'Ethnographic evidence relating to "trance" and "shamans" among northern and southern Bushmen', South African Archaeological Bulletin 47: 56-60.

Lewis-Williams, J. D. (1996) 'A visit to the Lion's house: the structure, metaphors and socio-political significance of a nineteenth-century Bushman myth' in J. Deacon and T. A. Dowson (eds), Voices from the Past: |Xam Bushmen and the Bleek and Lloyd Collection. Johannesburg: Witwatersrand University Press.

Lewis-Williams, J. D. (1997) 'The Mantis, the Eland and the Meerkats: conflict and mediation in a nineteenth-century San myth' in P. McAllister (ed.), Culture and the Commonplace: anthropological essays in honour of David Hammond-Tooke. Johannesburg: Witwatersrand University Press.

Lewis-Williams, J. D. (2000) Stories that Float from Afar: ancestral folklore of the San of Southern Africa. Cape Town: David Philip.

Lewis-Williams, J. D. (2002) 'The Mantis, the Eland and the Meerkats: conflict and mediation in a nineteenth-century San myth' in J. D. Lewis-Williams, $A$ Cosmos in Stone: interpreting religion and society through rock art. Walnut Creek CA: AltaMira Press (reprint of Lewis-Williams 1997).

Lewis-Williams, J. D. (2003) Images of Mystery: rock art of the Drakensberg. Cape Town: Double Storey. Also published as L'Art rupestre en Afrique du Sud: mystérieuses images du Drakensberg. Paris: Éditions du Seuil.

Lewis-Williams, J. D. (2010) 'The imagistic web of San myth and landscape', Southern African Humanities 22: 1-18.

Lewis-Williams, J. D. (2012) 'Rock art and shamanism' in J. McDonald and P. Veth (eds), A Companion to Rock Art. Chichester: Wiley-Blackwell.

Lewis-Williams, J. D. (2013a) 'From illustration to social intervention: three nineteenth-century |Xam myths and their implications for understanding San rock art', Cambridge Archaeological Journal 23: 241-62.

Lewis-Williams, J. D. (2013b) 'Qwanciqutshaa, a nineteenth-century southern San mythological being: who is he and what does his name mean?', South African Archaeological Bulletin 68: 79-85.

Lewis-Williams, J. D. (2015a) Myth and Meaning: San-Bushman folklore in global context. Walnut Creek CA and Cape Town: Left Coast Press and University of Cape Town Press.

Lewis-Williams, J. D. (2015b) 'Texts and evidence: negotiating San words and images', South African Archaeological Bulletin 70: 53-63.

Lewis-Williams, J. D. (2016) 'The Jackal and the Lion: aspects of Khoisan folklore', Folklore 127: 51-70.

Lewis-Williams, J. D. and M. Biesele (1978) 'Eland hunting rituals among northern and southern San groups: striking similarities', Africa 48: 117-34.

Lewis-Williams, J. D. and S. Challis (2011) Deciphering Ancient Minds: the mystery of San Bushman rock art. London: Thames and Hudson.

Lewis-Williams, J. D. and D. G. Pearce (2004a) San Spirituality: roots, expressions and social consequences. Cape Town and Walnut Creek CA: Double Storey and AltaMira Press. 
Lewis-Williams, J. D. and D. G. Pearce (2004b) 'Southern African rock paintings as social intervention: a study of rain-control images', African Archaeological Review 21: 199-228.

Lloyd, L. C. (1889) A Short Account of Further Bushman Material Collected. London: David Nutt.

Marshall, L. (1962) '!Kung Bushman religious beliefs', Africa 32: 221-51.

Marshall, L. (1969) 'The medicine dance of the !Kung Bushmen', Africa 39: 347-81.

Marshall, L. (1976) The !Kung of Nyae Nyae. Cambridge MA: Harvard University Press.

Marshall, L. (1999) Nyae Nyae!Kung: beliefs and rites. Cambridge MA: Harvard University Press.

Marshall Thomas, E. (2003) 'The lion/Bushman relationship in Nyae Nyae in the 1950s: a relationship crafted in the old way', Anthropologica 45: 73-8.

McGranaghan, M. S. (2012) 'Foragers in the frontier: the |Xam Bushmen of the Northern Cape, South Africa, in the nineteenth century'. PhD thesis, University of Oxford.

McGranaghan, M. (2015) "My name did float along the road": naming practices and |Xam Bushman identities in the 19th-century Karoo (South Africa)', African Studies 74 (3): 270-89.

McGranaghan, M., S. Challis and J. D. Lewis-Williams (2013) 'Joseph Millerd Orpen's "A glimpse into the mythology of the Maluti Bushmen": a contextual introduction and republished text', Southern African Humanities 25: 137-66.

Mitchell, P. (2002) The Archaeology of Southern Africa. Cambridge: Cambridge University Press.

Mitchell, P. and S. Challis (2008) 'A "first" glimpse into the Maloti Mountains: the diary of James Murray Grant's expedition of 1873-4', Southern African Humanities 20: 399-461.

Orpen, J. M. (1874) 'A glimpse into the mythology of the Maluti Bushmen', Cape Monthly Magazine (N.S.) 9 (49): 1-13.

Penn, N. (2005) The Forgotten Frontier: colonists and Khoisan on the Cape's northern frontier in the 18th Century. Cape Town: Double Storey.

Schapera, I. (1930) The Khoisan Peoples of South Africa. London: Routledge and Kegan Paul.

Schmidt, S. (1970) 'Europäische volkserzählungen bei den Nama und Bergdama', Fabula 11: 32-53.

Schmidt, S. (1989) Katalog der Khoisan-Volkserzählungen des südlichen Afrikas. 2 volumes. Hamburg: Helmut Buske Verlag.

Schmidt, S. (2013) South African |Xam Bushman Traditions and their Relationships to Further Khoisan Folklore. Cologne: Rüdiger Köppe Verlag.

Silberbauer, G. B. (1981) Hunter and Habitat in the Central Kalahari Desert. Cambridge: Cambridge University Press.

Skotnes, P. (2007) Claim to the Country: the archive of Wilhelm Bleek and Lucy Lloyd. Cape Town and Athens $\mathrm{OH}$ : Jacana and Ohio University Press.

Solomon, A. (2009) 'Broken strings: interdisciplinarity and |Xam oral literature', Critical Arts 23: 26-41.

Spohr, O. H. (1962) Wilhelm Heinrich Immanuel Bleek: a bio-bibliographic sketch. Cape Town: University of Cape Town Libraries. 
Stow, G. W. (1905) The Native Races of South Africa: a history of the intrusion of the Hottentots and Bantu into the hunting grounds of the Bushmen, the Aborigines of the country. London: Swan Sonnenschein.

Valiente-Noailles, C. (1993) The Kua: life and soul of the central Kalahari Bushmen. Rotterdam: Balkema.

Weintroub, J. (2015) Dorothea Bleek: a life of scholarship. Johannesburg: Witwatersrand University Press.

Wessels, M. (2010) Bushman Letters: interpreting |Xam narrative. Johannesburg: Witwatersrand University Press.

Wilmsen, E. N. (1989) Land Filled with Flies: a political economy of the Kalahari. Chicago IL: University of Chicago Press.

\begin{abstract}
Indigenous significances of nineteenth-century |Xam San folktales are hard to determine from narrative structure alone. When verbatim, original-language records are available, meaning can be elicited by probing beneath the narrative and exploring the connotations of highly significant words and phrases that imply meanings and associations that narrators take for granted but that nonetheless contextualize the tales. Analyses of this kind show that three selected |Xam tales deal with a form of spiritual conflict that has social implications. Like numerous |Xam myths, these tales concern conflict between people and living or dead malevolent shamans. Using their supernatural potency, benign shamans transcend the levels of the San cosmos in order to deal with social conflict and to protect material resources. As a result, benign shamans enjoy a measure of respect that sets them apart from ordinary people.
\end{abstract}

\title{
Résumé
}

Il est difficile de distinguer les significations indigènes des contes folkloriques Xam San du $19^{\text {ème }}$ siècle de la structure narrative seule. Lorsque des textes sont disponibles in extenso dans la langue d'origine, il est possible d'en obtenir le sens en fouillant sous le narratif et en explorant les connotations de mots et expressions hautement significatifs qui impliquent des sens et des associations auxquels les narrateurs n'accordent pas grande importance mais qui néanmoins contextualisent les contes. Ce type d'analyse montre que trois contes |Xam choisis traitent d'une forme de conflit spirituel qui a des implications sociales. Comme beaucoup de mythes |Xam, ces contes ont trait au conflit entre les habitants et les chamans malveillants vivants ou morts. Les chamans bienveillants usent de leur puissance surnaturelle pour transcender les niveaux du cosmos San afin de traiter les conflits sociaux et de protéger les ressources matérielles. C'est pourquoi les chamans bienveillants bénéficient d'un certain respect qui les distingue des personnes ordinaires. 